\title{
Effects of Remacemide and its Metabolite FPL 12495 on Spike-Wave Discharges, Electroencephalogram and Behaviour in Rats with Absence Epilepsy
}

\author{
E. L. J. M. VAN LUIJTELAAR* and A. M. L. COENEN \\ NICI, Departmeni of Psychology, University of Nijmegen, P.O. Box 9104, 6500 HE Nijmegen, The Netherlands
}

(Accepted 12 January 1995)

\begin{abstract}
Summary-The effects of the anti-convulsant drug remacemide and one of its active metabolites FPL 12495 were examined in a genetic model for generalized absence epilepsy, the WAG/Rij strain of rats. Number, mean and total duration of spike-wave discharges were measured following oral administration of remacemide and FPL 12495, together with parameters of background electroencephalographic activity (EEG) and spontaneous behaviour in the recording cage. A decrease in the number of the spike-wave discharges was found after remacemide administration. At the highest dose there was near total suppression of the spike-wave discharges. There were no important effects on behaviour and on spectral content of the background EEG, suggesting that remacemide has little side effects. A decrease in the number of spike-wave discharges was also found after FPL 12495 gavage and there was a prolongation of the mean duration. Behavioural changes were only noticed after the highest dose. These were accompanied by changes in the spectral content and particularly by an increase in the amplitude of the delta and the high beta frequencies, together with a decrease in the spindle frequency range. FPL 12495 appeared to be more potent that remacemide in all its effects. The effects of mainly FPL 12495 are uncommon in the sense that so far no other investigated drug shows a decrease in the number together with an increase in the mean duration of the discharges. It seems that in contrast to other anti-epileptic drugs, FPL 12495 exerts a differential action on the two commonly distinguished mechanisms controlling number and duration.
\end{abstract}

Keywords--Remacemide, FPL 12495, absence epilepsy, WAG/Rij strain, genetic model, spike-wave discharges, EEG, spectral analyses.

Remacemide is a new anti-convulsant drug. In mice and rats it shows a specific and potent protection in the maximal electroshock seizure (MES) test (Garske et al., 1991; Palmer et al., 1992). It is also effective in suppressing audiogenic seizures and the drug inhibits NMDA and kainic acid induced convulsions and tonic seizures elicited by 4-amino pyridine (Cramer et al., 1993; Palmer et al., 1992). The anticonvulsant effects of remacemide appear to be somewhat specific for these tests since pentylenetetrazol, bicuculline, picrotoxin or strychnine induced convulsions are unaffected. The mechanism of remacemide is thought to be similar to phenytoin and other compounds which inhibit sustained repetitive firing of the fast $\mathrm{Na}^{+}$channel (McLean et al., 1983). It has been proposed that remacemide may offer a suitable treatment for patients with generalized tonic-clonic and complex partial seizures. The desglycine metabolite of remacemide, FPL $12495^{\circ}$, is an even more potent anti-

\footnotetext{
*To whom correspondence should be addressed.
}

convulsant than remacemide itself (Palmer et al., 1992) and is a considerably more potent antagonist of the fast $\mathrm{Na}^{+}$channel and at the NMDA receptor site than remacemide (Harris et al., 1992).

The molecular structures of remacemide and FPL 12495 and their action in MES and in other models for convulsive epilepsy does not predict unambiguously the actions of these drugs against another type of generalized epilepsy, absence epilepsy, since various types of anti-convulsants react differentially in absence epilepsy. Drugs effective against tonic clonic epilepsy such as carbamazepine and phenytoin, do not decrease but aggravate absence seizures. Other anti-convulsants such as diazepam and loreclezole reduce spike-wave discharges while typical anti-absence drugs such as ethosuximide and trimethadione decrease spike-wave activity (Ates et al., 1992; Micheletti et al., 1987; Peeters et al., 1988; Peeters, 1991). If remacemide would mimic the effects of carbamazepine and phenytoin, one may predict that spike-wave activity would be enhanced after remacemide. 
Genetic models are the pertinent choice among the models available for human absence epilepsy (Löscher, 1984) and such a model is the WAG/Rij strain of rats (Coenen et al., 1992a; van Luijtelaar and Coenen, 1986, 1989; van Luijtelaar et al., 1991). At an age of six months all members of this inbred strain show the electrophysiological and behavioural manifestations of generalized absence epilepsy. They exhibit spontaneously occurring spike-wave discharges mostly during periods with a low level of vigilance (Drinkenburg et al., 1991; van Luijtelaar et al., 1991). The pharmacological profile of these spike-wave discharges closely resembles the profile of human absence epilepsy (Peeters et al., 1988). It will be investigated in the present experiment whether remacemide and FPL 12495 have effects on generalized absence epilepsy as shown by rats of the WAG/Rij strain. In order to determine whether these drugs have also other effects, spontaneous behaviour and background EEG were additionally measured.

\section{METHODS}

Fifty-six male WAG/Rij rats, six months of age and weighing between $260-382 \mathrm{~g}$ were used as experimental subjects. Animals were individually housed and had always access to food and water. A $12-12 \mathrm{hr}$ light-dark cycle with bright white lights on at $20.00 \mathrm{hr}$, was maintained throughout the experiment. The experiment took place in the dark phase of the day, which is the time of day with the highest incidence of spike-wave discharges (van Luijtelaar and Coenen, 1988). The experimental room was then illuminated by a weak red light for which albino rats are unsensitive but which allowed us to observe the rats' behaviour.

EEG electrodes (Plastics One, MS 333/2-A) were implanted in the cortex under anaesthesia (Nembutal, $60 \mathrm{mg} / \mathrm{kg}$ i.p.). They were placed in the frontal and in the parietal/occipital region of the cortex with coordinates $A$ 2.0 , L 3.5 and A $-6.0, \mathrm{~L} 4.0$ respectively, with skull surface flat and bregma zero-zero. An earth electrode was placed in the cerebellum. The animals were allowed to recover for at least 10 days. Experiments were performed in freely moving animals singly housed in transparent EEG recording cages $(25 \times 25 \times 30 \mathrm{~cm})$.

Remacemide and FPL 12495 were supplied as the hydrochloride salt by Fisons Pharmaceuticals (Loughborough, U.K.). The compounds were dissolved in saline and remacemide was administered in doses of 20,40 and $80 \mathrm{mg} / \mathrm{kg}$ and FPL 12495 in doses of 10, 20 and $40 \mathrm{mg} / \mathrm{kg}$. Additionally, a control group was used and rats of this group received saline only. Each group consisted of 8 subjects. The rats were adapted to the recording conditions for $18 \mathrm{hr}$ and a base-line EEG was recorded for $1 \mathrm{hr}$, starting at $10.00 \mathrm{hr}$. Then, animals were given remacemide, FPL 12495 or solvent in a dose volume of $1 \mathrm{ml}$ orally and subsequently the EEG was recorded for 2 consecutive hours. Drugs were always administered at $11.00 \mathrm{hr}$. All animals were used only once.
The EEG signal was amplified and filtered by an Elema-Schönander polygraph and frequencies between 1 and $70 \mathrm{~Hz}$ were allowed to pass. The EEG was stored in digitized form on a magneto-optical disk (DATA Instruments, AT-CODAS). Spike-wave discharges were visually scored according to criteria elaborated elsewhere (van Luijtelaar and Coenen, 1986). Number, mean and total duration of spike-wave discharges were determined.

Additionally, the spectral content of the background EEG without spike-wave discharges, was determined during representative periods of passive wakefulness after the first hour following remacemide, FPL 12495 or saline administration. The minimum time period that was analysed for each subject was $35 \mathrm{sec}$. These epochs were digitized with a rate of 512 samples per second. The power spectrum was calculated by means of a Fast Fourier Transformation (FFT) with a bin density of $1 \mathrm{~Hz}$, whereby the power spectrum was normalized. $Z$-scores are then obtained with a mean of zero and a variance of 1 in order to compensate for interindividual differences in amplification (Coenen and van Luijtelaar, 1989). The content of the following EEG frequency bands were determined: the delta-band $(1-4 \mathrm{~Hz})$, the theta-band $(6-10 \mathrm{~Hz})$, the sigma-band $(11-14 \mathrm{~Hz})$, the beta 1-band $(15-30 \mathrm{~Hz})$ and the beta 2-band $(>30 \mathrm{~Hz})$.

Spontaneous on-going behaviour of the rats in their cages was observed through a window from an adjacent room. The duration of the following behaviour categories was quantified for $30 \mathrm{~min}$ starting $5 \mathrm{~min}$ after injection: locomotor behaviour interpreted as exploratory behaviour (walking, rearing, sniffing, digging), automatic behaviour (grooming, eating, drinking) and immobile behaviour (sitting, lying and standing still) (Coenen and van Luijtelaar, 1989; Vanderwolf, 1969). Data were recorded and analysed with the Observer (Noldus, 1991).

The overall effects induced by the compounds with respect to number and duration of spike-wave discharges, behaviour and EEG spectral analysis, were statistically analyzed by means of a one-factor (doses) ANOVA, while post-hoc comparisons according to Duncan were used to test differences between groups. The number of degrees of freedom were always 3 and 28 . The effects on spike-wave activity were evaluated for 60 min periods.

\section{RESULTS}

\section{Remacemide}

In Fig. 1(A), the number, mean and total duration of the spike-wave discharges are shown before and after the administration of saline, 20,40 and $80 \mathrm{mg} / \mathrm{kg}$ remacemide. Each bar in the histogram represents the values in a block of $60 \mathrm{~min}$ of recording. There were no differences between the four groups before drug administration. There were no differences on the number of spike-wave discharges between the four groups in the 

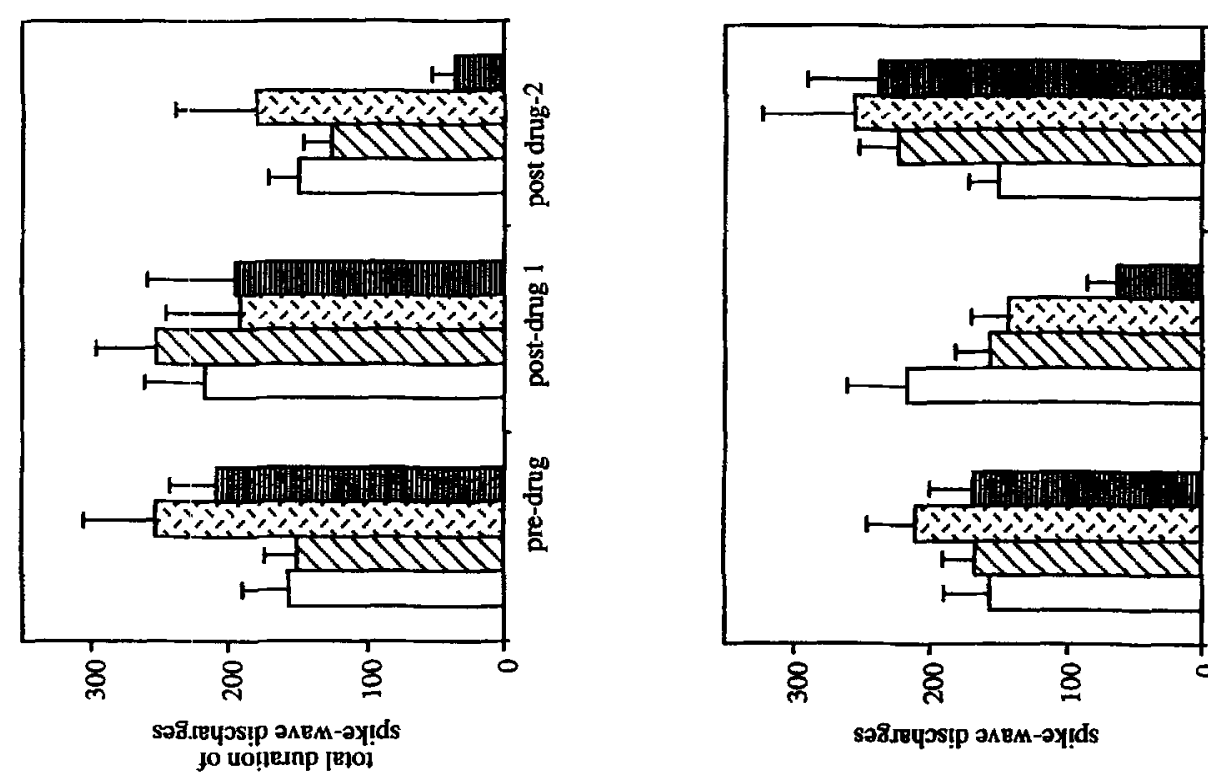



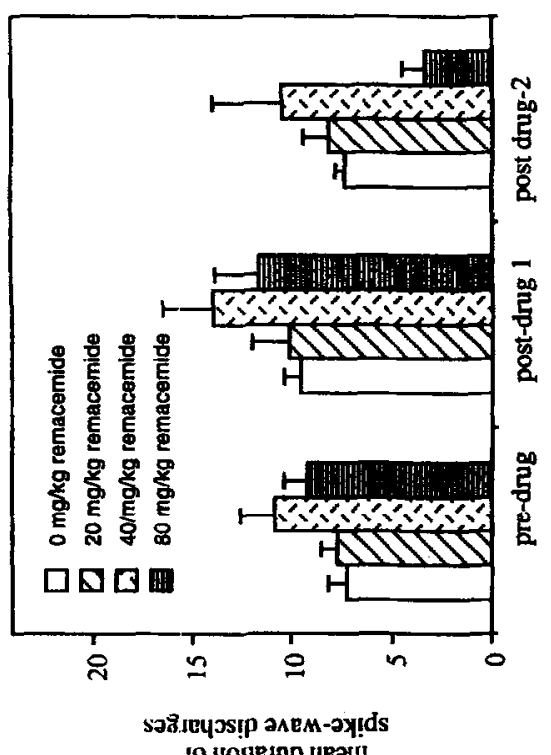

jo uogesnp urau
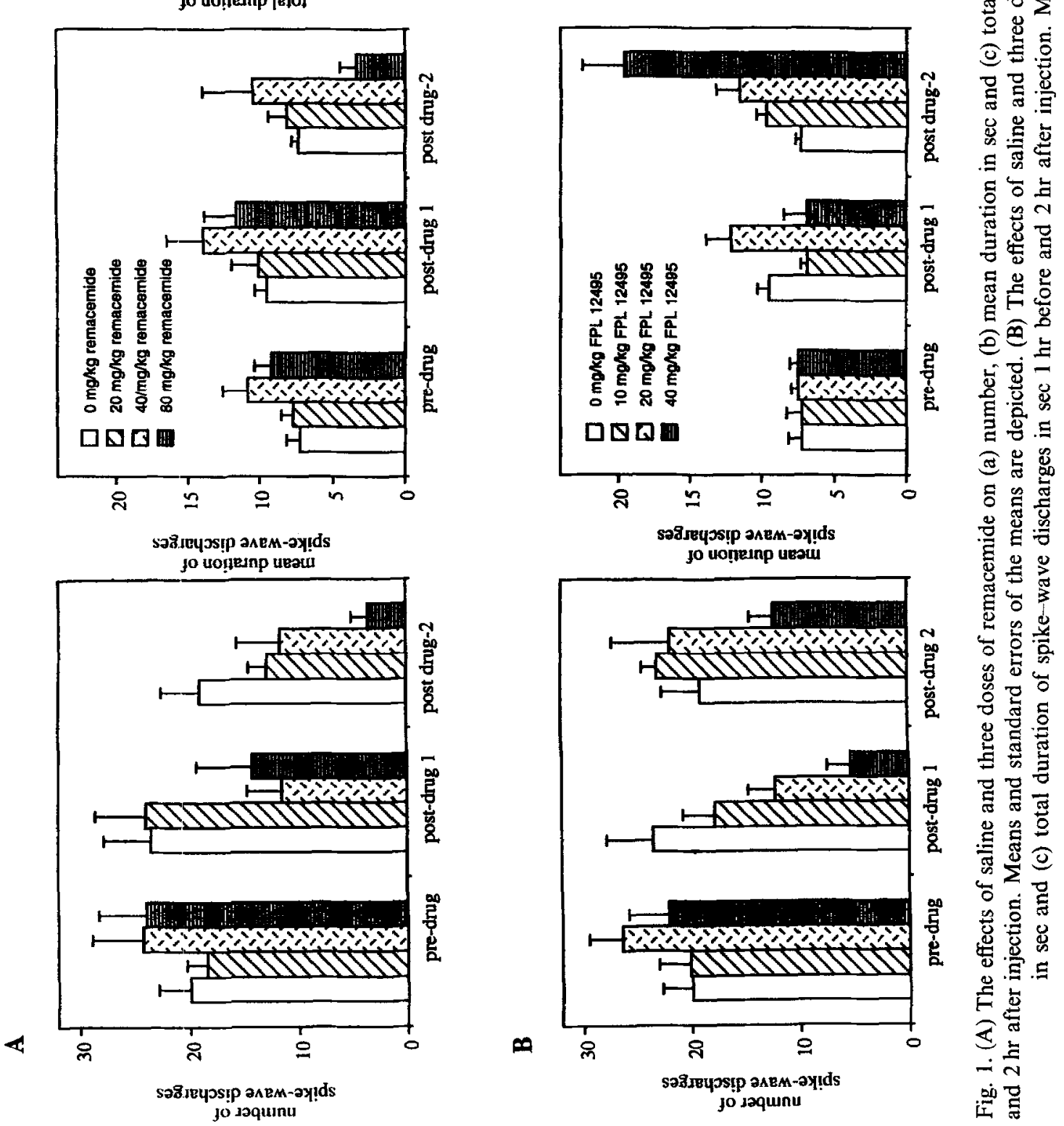
first hour after the animals were given remacemide. However, there was a significant effect in the second hour after administration $(F=4.85, P<0.01)$. The post-hoc test showed that the $80 \mathrm{mg} / \mathrm{kg}$ group had less spike-wave discharges than the saline and the $20 \mathrm{mg} / \mathrm{kg}$ group. Especially in the last $30 \mathrm{~min}$ remacemide became very effective: only one animal of the highest dose group showed just three spike-wave discharges, while the seven other rats had no spike-wave discharge left. Cochrans Q-test for dependent samples $(\mathrm{Q}=10,36, \quad \mathrm{Fg}=3$, alpha $=0.02$ ) confirmed that there were less animals with spike-wave discharges after $80 \mathrm{mg} / \mathrm{kg}$ remacemide than after solvent.

The mean duration of the spike-wave discharges was unaltered. The total duration of the spike-wave discharges showed also a significant effect in the second hour after administration $(F=3.58, P<0.05)$. The post-hoc test showed that the total duration of spike-wave discharges of the $80 \mathrm{mg} / \mathrm{kg}$ group was shorter than that of the 0 and $40 \mathrm{mg} / \mathrm{kg}$ groups.

The behavioural data presented in Table 1 showed no significant effects. The data of the background EEG analyses are presented in Fig. 2(A). Although a decrease in the power of the spindle and beta- 1 frequency band can be inferred from this figure, there were no significant changes in any of the frequency bands.

\section{FPL 12495}

In Fig. 1(B) the effects of FPL 12495 in doses of 10,20 and $40 \mathrm{mg} / \mathrm{kg}$ are shown on the number, mean and total duration of the spike-wave discharges. There were no differences between the four groups prior to FPL 12495 administration. There was a significant effect on the number of spike-wave discharges in the first hour after drug administration $(F=6.75, P<0.001)$ : after $40 \mathrm{mg} / \mathrm{kg}$ the number was decreased compared to $10 \mathrm{mg} / \mathrm{kg}$ and solvent and also after $20 \mathrm{mg} / \mathrm{kg}$ the number was decreased compared to solvent.
Table 1. Effects of remacemide and FPL 12495 on behaviour. Means and SEMs are given

\begin{tabular}{rccc}
\hline Dose & $\begin{array}{c}\text { Exploratory } \\
\text { behaviour }\end{array}$ & $\begin{array}{c}\text { Automatic } \\
\text { behaviour }\end{array}$ & $\begin{array}{c}\text { Immobile } \\
\text { behaviour }\end{array}$ \\
\hline $\begin{array}{c}\text { Remacemide } \\
0 \mathrm{mg} / \mathrm{kg}\end{array}$ & $26.1 \pm 1.5 \%$ & $32.5 \pm 7.2 \%$ & $41.4 \pm 8.2 \%$ \\
$20 \mathrm{mg} / \mathrm{kg}$ & $28.0 \pm 4.1 \%$ & $27.1 \pm 6.1 \%$ & $44.8 \pm 7.8 \%$ \\
$40 \mathrm{mg} / \mathrm{kg}$ & $25.3 \pm 6.0 \%$ & $42.4 \pm 9.0 \%$ & $32.2 \pm 10.8 \%$ \\
$80 \mathrm{mg} / \mathrm{kg}$ & $25.5 \pm 5.3 \%$ & $49.9 \pm 2.9 \%$ & $24.5 \pm 6.8 \%$ \\
$F P L 12495$ & & & \\
$0 \mathrm{mg} / \mathrm{kg}$ & $26.1 \pm 1.5 \%$ & $32.5 \pm 7.2 \%$ & $41.4 \pm 8.2 \%$ \\
$10 \mathrm{mg} / \mathrm{kg}$ & $29.3 \pm 4.6 \%$ & $40.0 \pm 8.0 \%$ & $30.7 \pm 8.9 \%$ \\
$20 \mathrm{mg} / \mathrm{kg}$ & $23.1 \pm 4.2 \%$ & $40.3 \pm 6.1 \%$ & $36.6 \pm 4.8 \%$ \\
$40 \mathrm{mg} / \mathrm{kg}$ & $40.5 \pm 6.3 \%$ & $26.5 \pm 4.3 \%$ & $31.2 \pm 6.4 \%$ \\
\hline
\end{tabular}

The mean duration of the spike-wave discharges was affected by the drug in the first $(F=3.90, P<0.05)$ and in the second $(F=9.57, P<0.001)$ hour post injection. In the first hour the duration of $20 \mathrm{mg} / \mathrm{kg}$ group was longer than that of the 40 and $10 \mathrm{mg} / \mathrm{kg}$ groups. In the second hour the duration was prolonged after $40 \mathrm{mg} / \mathrm{kg}$ compared to 20,10 and $0 \mathrm{mg} / \mathrm{kg}$.

The total duration of the spike-wave discharges was only reduced in the first hour $(F=4.45, P<0.05)$ : the $40 \mathrm{mg} / \mathrm{kg}$ group differed from the 20,10 and $0 \mathrm{mg} / \mathrm{kg}$ groups.

The behavioural data are presented in Table 1. The animals tended to show more exploratory behaviour, but the effects did not reach significancy. The drug had an effect on the number of immobile periods $(F=4.76$, $P<0.01)$ : the post-hoc test showed that it was enhanced after $40 \mathrm{mg} / \mathrm{kg}$ only.

The data on the background EEG of FPL 12495 are presented in Fig. 2. A significant dose effect was found for the delta band $(F=3,31, P<0.05)$ : after $40 \mathrm{mg} / \mathrm{kg}$ group there was more delta activity than after $20 \mathrm{mg} / \mathrm{kg}$ or saline. There was a tendency for a dose effect in the theta band. In the spindle $(F=4,49, P<0.01)$ and in the beta- 2 band $(F=5,38, P<0.01)$ significant dose effects could be demonstrated: the amplitude was smaller in the
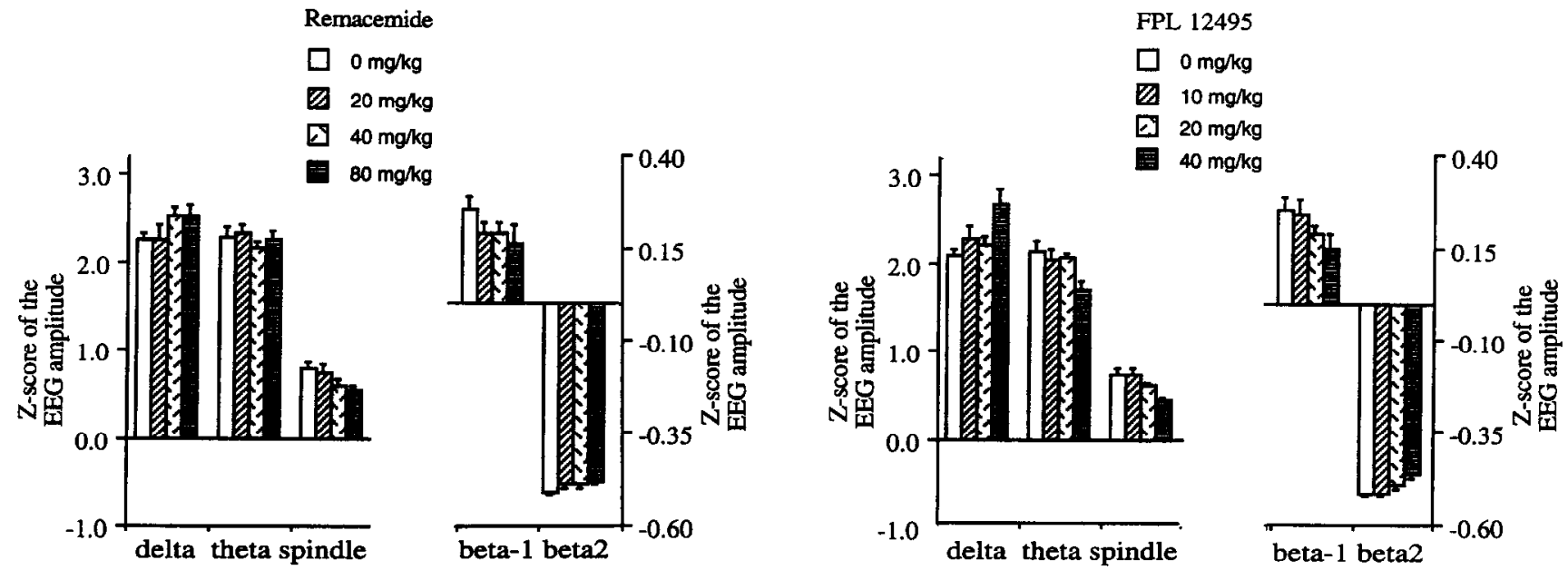

Fig. 2. (A) The effects of saline and three doses of remacemide on the background EEG. (B) The effects of saline and three doses of FPL 12495 on the background EEG. Means and standard errors are depicted. 
spindle band after $40 \mathrm{mg} / \mathrm{kg}$ compared to saline or to $10 \mathrm{mg} / \mathrm{kg}$, but larger in the beta- 2 band after $40 \mathrm{mg} / \mathrm{kg}$ compared to saline.

\section{DISCUSSION}

Although there are some clear differences between the two compounds with respect to time of onset and potency, the present data show that both remacemide and FPL 12495 decrease the number of spike-wave discharges in this genetic model for generalized absence epilepsy. The decrease in the number of spike-wave discharges after specifically remacemide application was found however in the highest dose and in the second hour only. This late onset is probably due to the oral administration of remacemide and to the fact that this drug has to be metabolized in order to become active and to suppress spike-wave discharges. Remacemide is metabolized into FPL 12495 and at its turn FPL 12495 is further metabolized into FPL 14465 and FPL 14330. In fact remacemide has nine identified and five potential metabolites (Palmer et al., 1992). Both metabolites FPL 14465 and FPL 14330 can be found in cerebrospinal fluid and in the plasma (Palmer et al., 1992) in rats but it is unknown whether these and other metabolites suppress spike-wave discharges. The decrease in epileptic activity was also evident from the decrease in the total duration of spike-wave discharges, again after the highest dose only and this was also particularly striking $90-120 \mathrm{~min}$ after administration. At that time only one single animal showed spike-wave discharges and only three in number: i.e. a mean of less than 0.5 spike-wave discharge compared to habitual twenty under base-line conditions. Since the plasma concentration after oral administration of remacemide peaks at $30 \mathrm{~min}$ and declines to approximately a quarter of that value in $2 \mathrm{hr}$, it seems likely that the firm suppression of the number of spike-wave discharges after $90-120 \mathrm{~min}$ can be more likely attributed to either a combined action of remacemide and active metabolites rather than to remacemide itself. The duration of the action of the active metabolites exceeded the $2 \mathrm{hr}$ recording period and therefore it remains unclear how long remacemide or their metabolites suppress spike-wave discharges.

FPL 12495 is more potent than remacemide in decreasing the number of spike-wave discharges and acts also faster than remacemide. FPL 12495 reaches its maximum plasma value after $30 \mathrm{~min}$ and remains constant for several hours (Palmer et al., 1992). Surprisingly, FPL 12495 increases the mean duration of spike-wave discharges. It is of interest that the effects on number and on mean duration of spike-wave discharges dissociate in two ways, firstly on time and secondly on direction. Firstly, the effects on the number are immediately present and stay limited to the first hour, while the effects on the mean duration tend to be present in the first hour and are larger in the second hour. This latter finding suggests that the effects on duration are due to a combined action of FPL 12495 and one or more of its active metabolites. Another possibility is that FPL 12495 is racemic and that its differential effects on time might be related to varying effects of the two isomers. Secondly, there is also a dissociation with respect to the direction of the induced changes in the anti-epileptic activity of FPL 12495. This compound suppresses the number of spike-wave discharges but it prolongs their mean duration; a decrease in the number together with an increase in the mean duration of the spike-wave discharges is striking and uncommon. Until now we and others have evaluated specific anti-absence drugs, anticonvulsants, broad spectrum anti-epileptics (Ates et al., 1992; Coenen and van Luijtelaar, 1989; Micheletti et al., 1987; Peeters et al., 1988; van Luijtelaar and Coenen, 1989), $\beta$-carbolines (Coenen et al., 1989, 1992b), quisqualate, kainate and NMDA receptor agonists and antagonists (Frey and Voits, 1991; Peeters et al., 1989; Peeters, 1991), GABA-ergic compounds (Micheletti et al., 1985; Peeters et al., 1989a), morphine-like analgesics (Frey and Voits, 1991) and opiates (Lason et al., 1994), dopaminergic agents (Buzsáki et al., 1990; Warter et al., 1988), central anticholinergics (Frey and Voits, 1991) and psychotropic and alpha-adrenergic agents (Kleinlogel, 1995; Vanderwolf, 1969). Although not all authors distinguished between the number and the mean duration of the spike-wave discharges, it was not remarked that any of these compounds decreased the number of spike-wave discharges associated with an increase of its mean duration. This means that the present data are rather uncommon in the sense that they indicate that a single compound and probably one of its metabolites may exert effects on number and mean duration in opposite ways.

It has to be remarked that the drug mechanisms involved in protection against spike-wave discharges might be quite different from those involved in protecting against maximal electroshock seizures. Phenytoin and carbamazepine are very effective in the maximal electroshock test, but they increase the numbers of spike-wave discharges (Peeters et al., 1988; van Luijtelaar and Coenen, 1989). Remacemide and FPL 12945 reduce the number of spike-wave discharges and they are effective in the maximal electroshock test (Palmer et al., 1992; Stagnitto et al., 1990). It seems however, that remacemide is more potent in the electroshock test at which an ED50 as low as $21.4 \mathrm{mg} / \mathrm{kg}$ was noticed. Here only $80 \mathrm{mg} / \mathrm{kg}$ was effective.

The level of vigilance and the number of spike-wave discharges have an intimate relationship. Few spikewave discharges can be expected during periods of high vigilance and active behaviour and vice versa (Coenen et al., 1992; Drinkenberg et al., 1991; van Luijtelaar et al., 1991). The present data show that the decrease in the number of spike-wave discharges after the highest dose of remacemide is not accompanied by clear changes in motor activity and by changes in the background EEG. 
The highest dose of FPL 12495 induced a tendency for more locomotor activity while the number of immobile periods was enhanced with shorter durations, implying some behavioural activation. Enhanced activity prevents the occurrence of spike-wave discharges and it cannot be excluded that the decrease in the number of spike-wave discharges is secondary to the increase in locomotor activity. However, the behavioural changes occurred only after the highest dose of FPL 12495 while the effects on the number of spike-wave discharges were already present after the middle dose. This suggests that the effects of FPL 12495 on spike-wave discharges are more due to its anti-epileptic action and not to its mild behavioural changes.

The spectral analysis of the background EEG did not reveal significant changes after remacemide. This suggests that remacemide has no effects on the background EEG activity as so many psychoactive drugs including anti-epileptics (Duncan, 1987; Krijzer et al., 1993). The highest dose of FPL 12495 induced changes in the spectral content: an increase in the delta and in the high beta range and a decrease in the spindle band. Krijzer et al. (1993) observed a power increase in the $35-100 \mathrm{~Hz}$ and a power decrease from 15 to $25 \mathrm{~Hz}$ in the frequency spectrum of some psychostimulant drugs. The effects on the spectral content might be related to a yet unknown common property of FPL 12495 and these psychostimulant drugs, perhaps a high affinity for the non-competitive NMDA receptor (Harris et al., 1992).

It can be concluded that remacemide has some antiabsence activity in this model and that its active metabolite, FPL 12495, also reduces absence activity in spite of a tendency to increase the mean duration of spike-wave discharges. FPL 12495 seems more potent than remacemide in reducing the number of spike-wave discharges. The combination of the decrease in number and increase in mean duration, in particular for FPL 12495 is rather uncommon and offers a way to separate the mechanisms responsible for the onset and the duration of spike-wave discharges. FPL 12495 has effects on behaviour and an EEG profile with some similarity to that of psychostimulant drugs. Remacemide has no large effects on behaviour and does not affect the background EEG and it should be tried in intractable types of absence epilepsy.

Acknowledgements - We would like to thank Egid Blezer and Thijs Janssen for their valuable contributions to this study.

\section{REFERENCES}

Ates N., Van Luijtelaar E. L. J. M., Drinkenburg W. H. I. M., Vossen J. M. H. and Coenen A. M. L. (1992) Effects of Loreclezole on epileptic activity and on EEG and behaviour in rats with absence seizures. Epilepsy Res. 13: 43-48.

Buzsáki G., Laszlovsky I., Lajthma A. and Vadász C. (1990) Spike-and-wave neocortical patterns in rats: genetic and aminergic control. Neuroscience 38: 323-333.

Coenen A. M. L. and Van Luijtelaar E. L. J. M. (1989) Effects of diazepam and two beta-carbolines on epileptic activity and on EEG and behaviour in rats with absence seizures. Pharmac. Biochem. Behav. 32: 27-35.

Coenen A. M. L., Drinkenburg W. H. I. M., Peeters B. W. M. M., Vossen J. M. H. and Van Luijtelaar E. L. J. M. (1991) Absence epilepsy and the level of vigilance in rats of the WAG/Rij strain. Neurosci. Biobehav. Rev. 151: 259-263.

Coenen A. M. L., Drinkenburg W. H. I. M., Inoue M. and Van Luijtelaar E. L. J. M. (1992a) Genetic models of absence epilepsy, with an emphasis on the WAG/Rij strain of rats. Epilepsy Res. 12: 75-88.

Coenen A. M. L., Stephens D. N. and Van Luijtelaar E. L. J. M. (1992b) Effects of the beta-carboline abecarnil on epileptic activity, EEG, sleep and behaviour of rats. Pharmac. Biochem. Behav. 42: 401-405.

Cramer C. L., Stagnitto M. L., Knowles M. A. and Palmer G. C. (1993) Kainic acid and 4-amino pyridine seizure models in mice: evaluation of efficacy of anti-epileptic agents and calcium antagonists. FASEB 7 part 1: PA32, no 185.

Drinkenburg W. H. I. M., Coenen A. M. L., Vossen J. M. H. and Van Luijtelaar E. L. J. M. (1991) Spike-wave discharges and sleep-wake states in rats with absence epilepsy, Epilepsy Res. 9: 218-224.

Duncan J. S. (1987) Antiepileptic drugs and the electroencephalogram. Epilepsia 28: 259-266.

Frey H. H. and Voits M. (1991) Effect of psychotropic agents on a model of absence epilepsy in rats. Neuropharmacology 30: $651-656$.

Garske G. E., Palmer G. C., Napier J. J., Griffiths R. C., Freedman L. R., Harris E. W., Ray R., McCreedy S. A., Blosser J. C., Woodhead J. H., White H. S. and Swinyard E. A. (1991) Preclinical profile of the anticonvulsant remacemide and its entiomers in the rat. Epilepsy Res. 9: 161-174.

Griffith R., Napier J., Murray R., Gentile R., Loch J., De Cory T., Palmer G., Blosser J., Ray R. and Stagnitto M. (1990) Remacemide: a prodrug NMDA antagonist. Int. Symp. Med. Chem. 11: 30.

Harris E., Stagnitto M., Garske G. Crefgan E., Ray R., Julien R., Wilson T., Machulskis G., Biabolok X., White J. and Palmer G. (1992) In: Multiple Sigma and PCP Receptors Ligands: Mechanisms for Neuromodulation and Neuroprotection (Kamenka J. M. and Domino E. F. Eds), pp. 643-652. NPP Books, Ann Arbor.

Kleinlogel H. (1985) Spontaneous EEG paroxysms in the rat: effects of psychotropic and alpha-adrenergic agents. Neuropsychobiology 13: 206-213.

Krijzer F., Koopman P. and Olivier B. (1993) Classification of psychotropic drugs based on pharmaco-electroencephalographic studies in vigilance-controlled rats. Neuropsychobiology 28: $122-137$.

Lason W., Przewlocka B., Coenen A., Przewlocki R. and Van Luijtelaar G. (1994) Effects of mu and delta opioid receptor agonists and antagonists on absence epilepsy in WAG/Rij rats. Neuropharmacology 33: 161-166.

Löscher W. (1984) Genetic animal models of epilepsy as a unique resource for the evaluation of anticonvulsant drugs: a review. Meth. Findings Exp. Clin. Pharmac. 6: 531-547. van Luijtelaar E. L. J. M. and Coenen A. M. L. (1986) Two types of electrocortical paroxysms in an inbred strain of rats. Neurosci. Lett. 70: 393-397.

van Luijtelaar E. L. J. M. and Coenen A. M. L. (1988) 
Circadian rhythmicity in absence epilepsy in rats. Epilepsy Res. 2: 331-336.

van Luijtelaar E. L. J. M. and Coenen A. M. L. (1989)

The WAG/Rij model for generalized absence seizures. In: Advances in Epileptology (Manelis J., Bental E., Loeber J. N. and Dreifuss F. E., Eds), Vol. 17, pp. 78-83. Raven Press: New York.

van Luijtelaar E. L. J. M., Van de Werf S. J., Vossen J. M. H. and Coenen A. M. L. (1991) Arousal, performance and absence seizures in rats. Electroenceph. Clin. Neurophysiol. 79: $430-434$.

McLean M. J. and MacDonald R. L. (1983) Multiple actions of phenytoin on mouse spinal cord neurons in cell culture. J. Pharmac. Exp. Ther. 227: 779-789.

Micheletti G., Marescaux C., Vergnes M., Rumbach L. and Warter J. M. (1985) Effects of GABAmimetics and GABA antagonists on spontaneous nonconvulsive seizures in Wistar rats. In: Epilepsy and GABA Receptor Agonists. Basic and Therapeutic Research (Bartholini G., Bossi L., Lloyd K. G. and Morselli M. L., Eds), Vol. 3, pp. 129-137, L.E.R.S. Monograph series. Raven Press, New York.

Micheletti G., Warter J. M., Marescaux C., Depaulis A., Tranchant C., Rumbach L. and Warter J. M. (1987) Effects of drugs affecting the noradrenergic neurotransmission in rats with spontaneous petit mal-like seizures. Eur. J. Pharmac. 135: 397-402.

Noldus L. P. J. J. (1991) The observer: a software system for collection and analysis of observational data. Behav. Res. Meth. Instrum. Computers 23: 415-429.

Palmer G. C., Murray R. I., Wilson T. C. M., Eisman M. S., Ray R. K., Griffith R. C., Napier J. J., Fedorchuk M., Stagnitto M. L. and Garske G. E. (1992) Biological profile of the metabolites and potential metabolites of the anticonvulsant remacemide. Epilepsy Res. 12: 9-20.
Peeters B. W. M. M. (1991) Studies on the basic mechanisms underlying spike-wave discharges in rats. $\mathrm{PhD}$. Thesis, Nijmegen University.

Peeters B. W. M. M., Spooren W. P. J. M., Van Luijtelaar E. L. J. M. and Coenen A. M. L. (1988) The WAG/Rij model for absence epilepsy: anticonvulsant drug evaluation. Neurosci Res. Commun. 2: 93-97.

Peeters B. W. M. M., van Rijn C. M., van Luijtelaar E. L. J. M. and Cocnen A. M. L. (1989a) Antiepileptic and behavioural actions of MK-801 in an animal model of spontaneous absence epilepsy. Epilepsy Res. 3: 178-181.

Peeters B. W. M. M., van Rijn C. M., Vossen J. H. M. and Coenen A. M. L. (1989b) Effects of GABA-ergic agents on spontaneous non-convulsive epilepsy, EEG and behaviour in the WAG/Rij strain. Life Sci. 45: 1171-1176.

Riekkinen P., Sirvio J., Riekkinen M., Lammintausta R. and Riekkinen P. (1992) Atipamezole, an a2 antagonist, stabilizes age-related high-voltage spindle and passive avoidance defects. Pharmac. Biochem. Behav. 41: 661-664.

Stagnitto M. L., Palmer G. C., Ordy J. M., Griffiths R. C., Napier J. N., Becker, C. N., Gentile R. J., Garske G. E., Frankenheim J. M., Woodhead J. H., White H. S. and Swinyard E. A. (1990) Preclinical profile of remacemide: a novel anticonvulsant effective against maximal electroshock seizures in mice. Epilepsy Res. 7: 11-28.

Vanderwolf C. H. (1969) Hippocampal electrical activity and voluntary movement in the rat. Electroencephalography. Clin. Neurophysiol. 26: 407-418.

Warter J. M., Vergnes M., Depaulis A., Tranchant C., Rumbach L., Micheletti G. and Marescaux C. (1988) Effects of drugs affecting dopaminergic neurotransmission in rats with spontaneous petit-mal-like seizures. Neuropharmacology 27: 269-274. 